\title{
A HEALTH STUDY OF A BOYS' SCHOOL*
}

\author{
RICHARD M. SMITH, M.D. \\ BOSTON
}

The health of schoolchildren has been a matter of interest to physicians and school authorities for many years. This interest has been given an added impetus as a result of the war and the general awakening to the importance of child life. Thus far the care of the health of schoolchildren has been for the most part along conventional lines. The primary effort has been directed toward the detection of physical defects and the listing of them. Notice has been sent to parents telling them of the need for treatment. In some instances treatment has been secured through the follow-up work of school nurses. Recently special school clinics, notably, dental clinics, have been established for correction of defects. This is especially true in communities where hospital facilities are inadequate. This development is a distinct advance over the work of previous years, but there is much still to be wished for in this direction. It has been customary also in some schools to provide lunches. For the last two years there has been unusual interest in malnutrition. This interest has resulted in a considerable measure from the weighing and measuring tests of young children instituted by the Children's Bureau. With the discovery of the prevalence of malnutrition has come a new emphasis on the necessity of proper food. Special classes have been formed for the feeding of underweight children.

In many schools the entire plan, as outlined above, for taking care of the health of the pupils has been in operation, and in nearly all schools some part of it. In only a few schools has there been any study of the health of the children taking into account all factors in the child's life and their relation to one another. The public schools have been more progressive than the private schools in this matter. In fact, many private schools, excellent in other respects, entirely neglect the question of health.

As pediatricians whose chief responsibility has to do with the health of children, there are certain matters concerning which I believe we should take definite action. These matters have to do with the quality of care given at present to the health of schoolchildren and with further needed extension of care. There are certain minimum standards of health supervision to which every schoolchild is entitled.

* Read at the Annual Meeting of the American Pediatric Society, held at Atlantic City, June 16-18, 1919. 
In the first place, we should demand that every schoolchild be given a complete physical examination at least once a year, and means provided for the correction of defects and the treatment of diseases found. At the same time we should see to it that defects or diseases do not develop while the child is in school. Physical examinations should be made by a competent physician and made with the child undressed. I am told that at a recent meeting of a state medical society a well known school physician in a large city argued that it was impossible to undress schoolchildren for examination, and that we must content ourselves with the imperfect results obtained by unsatisfactory methods. I do not believe parents have any objection to an examination, provided they understand why the examination is made. Good medical advice cannot be given without careful examinations.

In the second place, we should insist on proper qualifications for school nurses. School nurses are really health instructors, and they must be selected because of efficiency in that work, not because of any other reason.

In the third place, we should bring about a better understanding and a closer cooperation between the school authorities and the family physician, and the practicing dentist. Often the advice given at school and that given at home are entirely different. The difference usually arises because of a failure of understanding. Unity of action must be secured for the good of the child's health. If minimum health standards for schoolchildren were established and taught, there would be no conflict of advice. This involves the introduction of the teaching of school hygiene in the medical schools - a development which is sure to come in time, and which I believe we should try to secure at once.

In the fourth place, we should continue our recent interest in the question of nutrition. We must recognize in this connection that the study and special care of undernourished children does not include the whole problem. It is not sufficient to weigh and measure all schoolchildren and then confine all our attention to those who prove to be underweight. This method gives no recognition to the equal importance of preventing malnutrition in those who at the present time may be of normal weight. It is to be borne in mind also that our standards for weight and height are by no means positively established. It is quite possible that the true normal may be of wide variation. We must, therefore, see to it that all the children are in good nutritional condition. To this end school lunches of the right kind should be provided for all the children, and some supervision given to the methods in which the lunch is eaten. 
In looking toward the future extension of health supervision there are certain additional features to which we must direct our attention.

First.-There must be a general recognition of the importance of health. The recent draft has shown that our present methods of safeguarding health do not produce satisfactory results. The army required healthy men as its requisite for service. Health is just as necessary for efficiency in peace as in war. This principle is fundamental for further progress.

Second.-There must be a realization among school authorities, both private and public, that the health of children is as important as scholarship, and that education must not go at the expense of health. In many individuals this will involve a complete change in point of view with reference to school problems, and in many instances a radical readjustment of the school program.

Third.-There is especial need of securing the cooperation of parents in protecting the health of their children. In general, parents have failed to realize the importance of health in connection with school. I believe this is due to lack of information. They are particularly careless in the planning of activities outside of school hours, such as special lessons and parties. These activities must be planned in connection with the school work, and not be added to that without reference to other matters. The child's life cannot be divided between school and home hours, and each planned independently, if good results are to be obtained. The school master and the parent, and those interested in child welfare, with the advice of the physician, must act together and see that the child's life as a whole is lived so as to protect and not injure his health.

Fourth.-It is important that the pupils themselves receive instruction regarding health. The teaching of health to pupils must be eventually in the hands of the school authorities. This can be done only when the school authorities recognize the importance of health and after they have received from physicians information as to the proper things to teach. This makes it necessary for us to be ready to submit courses of instruction for teaching health to children. Thus far there has been very little thought given to this matter, either by physicians or by anyone else. We must consider it, however, in the immediate future if we wish to have the right things taught.

I have stated my conclusions first, because they. seem to me of more value in that position. What I have to say with reference to the particular school is a description of the methods used there to safeguard the health of the children. I have had an opportunity of working with the head of the school in a practical demonstration of the principles which I have described. 
Mr. Rivers' Open Air School for Boys in Boston was started in 1915. From the beginning health has been considered equal in importance to education.

There is an advisory medical committee to whom the details of the curriculum are submitted in order that education and health may be considered in relation to each other. The work of the school is conducted entirely in open air classrooms. The food is approved by the medical members of the advisory committee. The children have rest periods each day. This is a definite part of the curriculum, and adapted to the varying needs of the boys of different ages. This is particularly important with the younger boys, who cannot get the full benefit of school without the periods of rest. Each boy's school program is explained in detail to his parents and the importance of planning home time in relation to this program is emphasized. The parents are told that they cannot expect good results in scholarship or health unless they consider the life of the boy as a unit. The school sends the boy to his family physician for advice when the progress in school or the health of the boy is suffering from a physical condition needing correction.

There is a school matron, corresponding to the school nurse in the public school, whose sole duty is to look after the health of the children. She does this under the direct supervision of the head of the school with the advice of the medical committee.

Every pupil on admission to the school brings a medical chart filled out by his parents or by the family physician, a form of which is shown, giving the medical background of the boy. This is considered carefully in planning his school work, his rest periods, his diet and any special supervision which is necessary. Each boy is given a complete physical examination at the opening of the school year. On the basis of this physical examination in conjunction with his medical history his school program is determined, and he is listed in one of several groups, either as "normal" or "for general observation," or as "overtire," i. e., a boy who has to be watched because of the possibility of fatigue, or as "colds," i. e., catches cold easily, etc.

The hours at school are divided into four groups, study, inactive, active and occupation. This is done in the belief that for each child there is a proper balance between his hours of study, activity and inactivity during each day. So far as the school is concerned, this can be carried out accurately. For its complete application it requires the willingness on the part of the parent to cooperate. Although the hours at school represent most of the boy's day, there is time before school and especially after school at night when there may be no supervision. If these out of school hours are given no thought, in connection with 
his school routine, his balance of time is disturbed. The number of hours of study for a boy of given age and grade is pretty constant and must remain so if he is to do the required amount of work and advance. The number of hours of inactivity, activity and occupation may be planned according to each boy's requirements. By periods of activity is meant school athletics and recess; by inactivity the rest period and dinner hour.

From a study of the boys in the school over a period of several years it has been determined that the following percentages of time represent about what the average boy of a given age can do without injury to his health and make satisfactory progress in his studies.

Table 1.-Standard Percentage of Time Given to Study, INACTIVITY AND ACTIVITY

\begin{tabular}{|c|c|c|c|}
\hline Age & Study & Inactivity & Activity \\
\hline 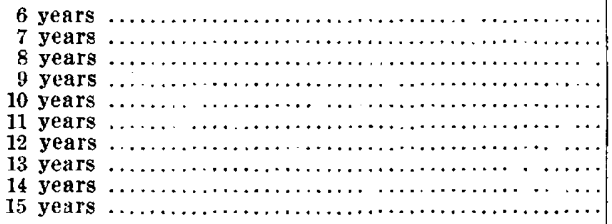 & $\begin{array}{l}4 \\
5 \\
5 \\
5 \\
5 \\
51 / 2 \\
51 / 2 \\
51 / 2 \\
51 / 2 \\
51 / 2\end{array}$ & $\begin{array}{l}3 \\
21 / 2 \\
2 \\
2 \\
2 \\
2 \\
11 / 2 \\
11 / 2 \\
11 / 2 \\
11 / 2\end{array}$ & $\begin{array}{l}2 \\
2 \\
21 / 2 \\
21 / 2 \\
21 / 2 \\
21 / 2 \\
21 / 2 \\
21 / 2 \\
3 \\
3\end{array}$ \\
\hline
\end{tabular}

It will be seen as the children grow older, the study hours increase slightly, the periods of rest decrease and the periods of activity increase. Each boy's schedule in percentages is checked against the formula for his age. This method has been of great value in many instances where boys were not doing well. This is not unlike the use which is made of caloric requirements in infants' feeding.

Every boy when he gets to school each morning is checked in on a chart by the matron. At this time inquiry is made as to his health. The matron also makes a superficial estimate of whether the boy looks well or not. If she is in doubt, the matter is pursued further. She sees that his clothes are right for the day. If a boy is not present and the reason is not known, the parents of the child are called on the telephone and the reason determined. The parent is asked, if the cause of absence is illness, where it was contracted. This is done in order that a record may be kept of whether the school was in any way responsible for the illness, i. e., whether it could have been prevented by any modification of the general school program or of that particular boy's program.

There is a general list of boys who need special attention which is posted in every school bungalow in order that the teacher may see and keep in mind the children in his class who require unusual care from 
the health point of view. If a boy on any particular day requires additional attention, the matron, at the time of checking in, makes a note of it. A list of these boys is taken to the teachers in charge of their rooms. Each boy when he leaves the school in the afternoon is checked out. At this time the matron sees that he has on enough sweaters to ride home; that he is not too hot or too cold or that his feet are not wet, and that he is physically in good condition. There is also noted in his checking out, if he leaves at any unusual time, the reason for it or any special comment. By this means of checking in and out, I feel confident that a great amount of good results. It makes a particular person responsible for the health of every boy each day. Between the time of checking in and checking out the matron spends her time in the schoolrooms, being sure that the boys who need special attention are receiving it. She sees that they are properly dressed for exercise and in general keeps track of the health program as outlined by the school.

A chart of absences is kept on which is recorded each day all the absences and the reasons in order that it may be visualized to compare with other days. There is recorded on this chart also the daily temperature and the kind of weather. A study of this chart reveals several interesting things. There is a remarkably small amount of contagious disease. This, I believe, is due to the constant effort on the part of the school to exclude any possible sources of infection. Children are kept from school whenever there is known illness of this character at home. The chart shows a variation in respiratory diseases, primary colds, running with modification in the weather. It shows also the small number of cases of illness which can be traced in any way to the school. Table 2 is a summary of the chart.

TABLE 2.-ABSENCES

\begin{tabular}{|c|c|c|}
\hline \multirow{2}{*}{\multicolumn{3}{|c|}{ 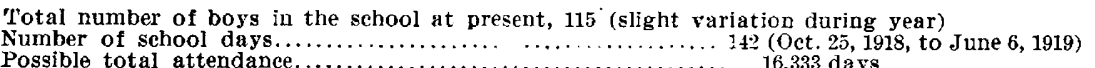 }} \\
\hline & 16,333 days & \\
\hline Days lost through colds............. & 859 days & $5.2 \%$ \\
\hline Days lost through contagion....... & 197 days & $1.2 \%$ \\
\hline 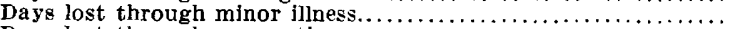 & 487 days & $2.9 \%$ \\
\hline 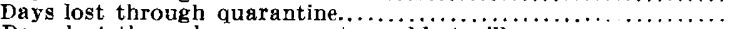 & 51 days & $0.3 \%$ \\
\hline 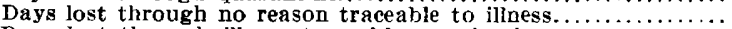 & 541 days & $33 \%$ \\
\hline Days lost through illness traceable to school................ & 94 days & $0.5 \%$ \\
\hline
\end{tabular}

There is a table of some of the boys who were below par on entrance, as indicated by being underweight. The progress during the year, the gain in weight, the scholarship record, the number of days absent and the usual reason are also shown. It will be seen that many of the boys made good progress in scholarship but had colds, and that others made good progress despite the fact that they did not make satisfactory gains in weight. A similar table might be shown of boys 
who did not make good progress in scholarship or who had many absences due to illness, but who had a normal weight at entrance and made good gain in weight during the year. Some of these boys had a physical handicap accounting for their poor scholarship, which was corrected, and then they did well in school work. These boys would have been neglected in health and in scholarship if the weight only had been considered as an index of health.

TABLE 3.--School Progress of Underweight Children

\begin{tabular}{|c|c|c|c|c|c|c|}
\hline Name & $\begin{array}{l}\text { Weight } \\
\text { Oct. } 1918\end{array}$ & $\begin{array}{l}\text { Underweight } \\
\text { for Height }\end{array}$ & $\begin{array}{c}\text { Gain in } \\
\text { Weight } \\
\text { During } \\
\text { Year }\end{array}$ & $\begin{array}{l}\text { Scholar- } \\
\text { ship }\end{array}$ & $\begin{array}{c}\text { Days } \\
\text { Absent }\end{array}$ & $\begin{array}{c}\text { Usual } \\
\text { Reason }\end{array}$ \\
\hline $\begin{array}{c}\text { B. } \\
\text { B. } \\
\text { C. } \\
\text { G. } \\
\text { K. } \\
\text { P. } \\
\text { P. } \\
\text { MeP. } \\
\text { P. } \\
\mathbf{W} . \\
\mathbf{W} .\end{array}$ & $\begin{array}{l}65 \text { lbs. } 13 \mathrm{oz} . \\
83 \text { lbs. } 12 \mathrm{oz} . \\
61 \mathrm{lbs} .5 \mathrm{oz} . \\
53 \text { lbs. } 15 \mathrm{oz} . \\
56 \text { lbs. } \\
67 \text { lbs. } 12 \mathrm{oz} . \\
65 \text { lbs. } 8 \mathrm{oz} . \\
75 \mathrm{lbs} .3 \mathrm{oz} . \\
88 \mathrm{lbs} .10 \mathrm{oz} . \\
58 \mathrm{lbs} . \\
58 \mathrm{lbs} .10 \mathrm{oz} .\end{array}$ & $\begin{array}{l}5 \text { lbs. } 3 \mathrm{oz} . \\
15 \mathrm{lbs} .4 \mathrm{oz} . \\
10 \mathrm{lbs} .11 \mathrm{oz} . \\
6 \mathrm{lbs} .1 \mathrm{oz} . \\
6 \mathrm{lbs} . \\
7 \mathrm{lbs} .4 \mathrm{oz} . \\
11 \mathrm{lbs} .8 \mathrm{oz} . \\
24 \mathrm{lbs} .13 \mathrm{oz} . \\
18 \mathrm{lbs} .6 \mathrm{oz} . \\
4 \mathrm{lbs} . \\
3 \mathrm{lbs} .6 \mathrm{oz} .\end{array}$ & $\begin{array}{l}2 \text { lbs. } 11 \mathrm{oz} . \\
9 \text { lbs. } 6 \mathrm{oz} . \\
3 \text { lbs. } 4 \mathrm{oz} . \\
2 \mathrm{lbs} .3 \mathrm{oz} . \\
1 \mathrm{lb} .2 \mathrm{oz} . \\
2 \text { lbs. } 14 \mathrm{oz} . \\
4 \text { lbs. } 4 \mathrm{oz} . \\
8 \text { lbs. } 5 \mathrm{oz} . \\
9 \text { lbs. } 10 \mathrm{oz} . \\
2 \text { lbs. } 10 \mathrm{oz} . \\
2 \text { lbs. } 3 \mathrm{oz} .\end{array}$ & $\begin{array}{l}\text { Good } \\
\text { Good } \\
\text { Excellent } \\
\text { Good } \\
\text { Excellent } \\
\text { Excellent } \\
\text { Good } \\
\text { Excellent } \\
\text { Excellent } \\
\text { Excellent } \\
\text { Good }\end{array}$ & $\begin{array}{r}6 \\
12 \\
7 \\
12 \\
25 \\
\\
6 \\
6 \\
2 \\
6 \\
3 \\
5\end{array}$ & $\begin{array}{l}\text { Colds } \\
\text { Colds } \\
\text { Colds } \\
\text { Colds } \\
\text { Colds and chick- } \\
\text { enpox } \\
\text { Colds } \\
\text { Minor } \\
\text { Minor } \\
\text { Minor } \\
\text { Minor } \\
\text { Chickenpox }\end{array}$ \\
\hline
\end{tabular}

It may be worth while to cite the record of a few boys.

CASE 1.-B., 12 years of age; normal weight for height. Had a history of repeated colds. Physical examination was negative except for a rather "ragged" throat. His progress in school was slow. He was absent often. Colds were cured by medical treatment, and then progress in school was good and he passed from the lower end of the grade to a candidacy for first position. His attendance was normal.

CASE 2.-D., 9 years of age; was underweight for his height (11 per cent.), and in poor general condition. Physical examination was negative except for the undernourishment. $\mathrm{He}$ did poor work at school and had many absences. A conference was held with his parents and the physician and it was found that after school at home he overexercised with resultant fatigue and interrupted sleep. His hours out of school were regulated in connection with the school schedule. The result was a marked improvement in school. His health is excellent, although he made only slight gain in weight ( $13 / 4$ pounds).

CASE 3.- H., 12 years of age, underweight (12 per cent.), with normal past history, except that he was "never robust." Physical examination negative except for the undernourishment. His scholarship was very bad. Absences were frequent. His schedule was arranged with special attention and more rest, and more supervision at meals to insure his taking the proper amount of food. The result was that his scholarship became excellent. His general condition was markedly improved. His weight is within a pound and a half of normal.

CASE 4.-F., 13 years of age; underweight (10 per cent.); gave a history of repeated colds. Physical examination was negative except for chronic infection of the tonsils with enlarged cervical glands. He did poor work at school and was absent repeatedly for tonsillitis. His tonsils were removed. His progress in school became excellent. He had no more absences and gained to within one and a half pounds of normal weight. 
OCT. NOV.

DEC.

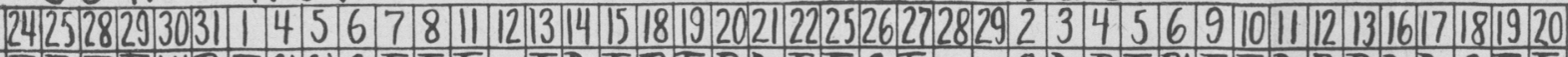
FFo.FFWRFCICICFE.F FDUFRFRDUFFCF CDURFBIFF DURR DuDuCF F Temp.

75
70
65
60
55
50
45
40
35
30
25
20

Absences

33

32

31

30

29

28

27

26

25

24

23

22

21

20

19

18

17

16

15

14

13

12

I

10

8

8

7
6
5
4

3

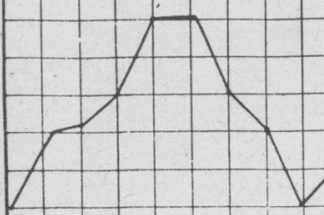

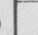

(25)
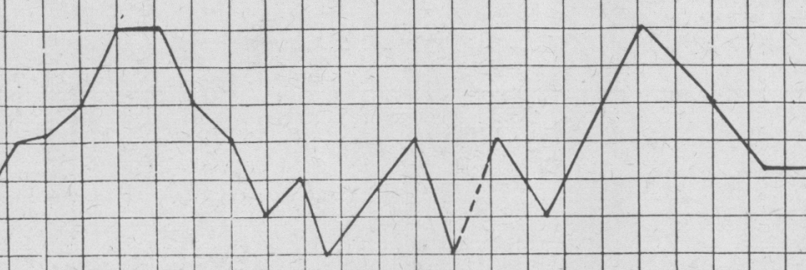

$\underbrace{1}$

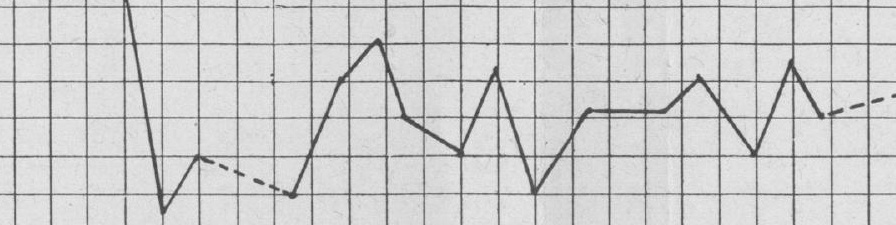

.

$-$

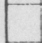

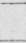

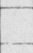

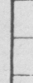

$1 \square$

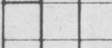

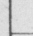

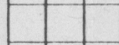


JAN.

FEB.

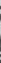
F DUR R DUDUCF F

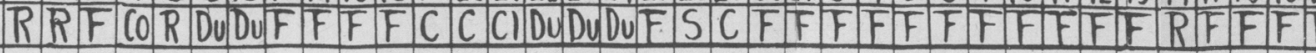

$\sqrt{1}+\cdots \sqrt{n}$

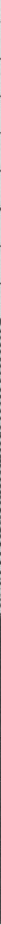




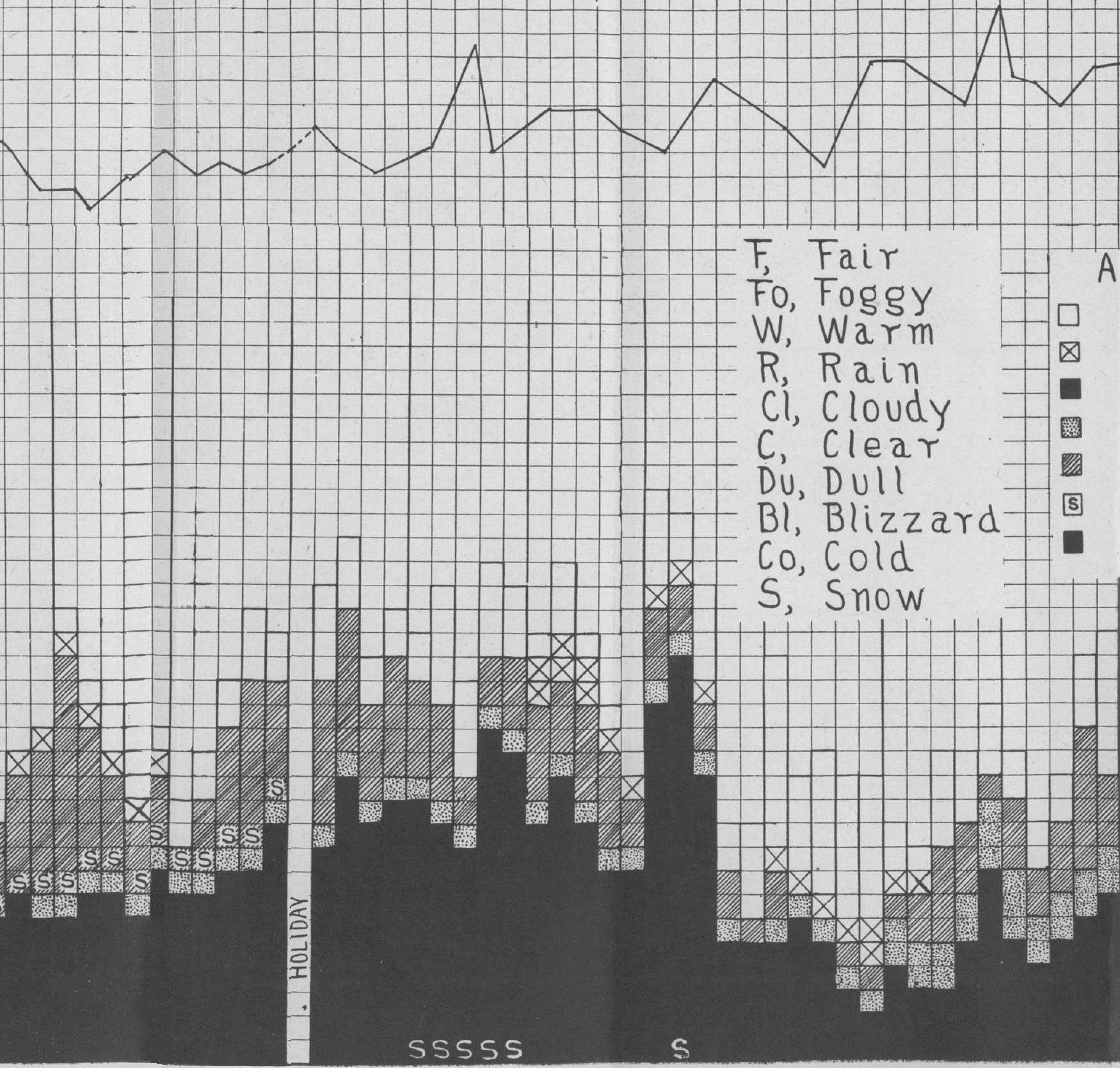







CASE 5.-P., 12 years of age; underweight (24 per cent.); had a history of repeated absences from school. He never felt well and made very poor progress in the classroom. Physical examination was negative, except for the marked undernourishment. It was quite evident that the difficulty with this boy was malnutrition and that he was constantly overtired. His schedule was made out with this in mind. By Christmas he began to show the effects of the special care. During the second half year he had no absences, and he is now one of the best students in the school. His gain in weight was only fair. He is now 16 per cent. underweight. Special watching by the matron made the change in this boy.

It is difficult to compare results from the health standpoint in this school with those in other schools, because of the lack of uniform standards of estimate. I am convinced, however, that progress in school health supervision must be in general along these lines: first, recognition by school authorities of the importance of health and the necessity of arranging school work with this in mind, and second, cooperation of parents and those interested in children in planning the time out of school in relation to the school program.

329 Beacon Street. 